\title{
Retraction Note to: Application of genetic programming (GP) and ANFIS for strength enhancement modeling of CFRP-retrofitted concrete cylinders
}

\author{
Mostafa Jalal $^{1} \cdot$ Ali A. Ramezanianpour ${ }^{1} \cdot$ Ali R. Pouladkhan ${ }^{2} \cdot$ Payman Tedro $^{2}$
}

Published online: 21 June 2021

(C) Springer-Verlag London Ltd., part of Springer Nature 2021

Retraction Note to: Neural Comput \& Applic (2013) 23:455-470

https://doi.org/10.1007/s00521-012-0941-2

The Editor-in-Chief has retracted this article because it shows significant overlap with a number of previously published articles [1-3].

Ali R. Pouladkhan and Mostafa Jalal do not agree with the Retraction. Ali. A. Ramezanianpour did not respond to correspondence regarding this retraction. The editor was not able to obtain a current email address for Payman Tedro.

\section{References}

1. Cevik A, Göğüş MT, Güzelbey İH, Filiz H (2010) Soft computing based formulation for strength enhancement of CFRP confined concrete cylinders. Adv Eng Softw 41(4):527-536. https://doi.org/ 10.1016/j.advengsoft.2009.10.015

2. Cevik A (2007) A new formulation for longitudinally stiffened webs subjected to patch loading. J Constr Steel Res 63(10):1328-1340. https://doi.org/10.1016/j.jcsr.2006.12.004

3. Cevik A (2007) A new formulation for web crippling strength of cold-formed steel sheeting using genetic programming. J Constr Steel Res 63(7):867-883. https://doi.org/10.1016/j.jcsr.2006.08. 012

Publisher's Note Springer Nature remains neutral with regard to jurisdictional claims in published maps and institutional affiliations.

The original article can be found online at https:// doi.org/10.1007/s00521-012-0941-2.

Mostafa Jalal

mjalal@aut.ac.ir

1 Concrete Technology and Durability Research Center, Amirkabir University of Technology, Tehran, Iran

2 Department of Civil Engineering, Razi University, Kermanshah, Iran 